\title{
The ATP-dependent RNA helicase HrpB plays an important role in motility and biofilm formation in Xanthomonas citri subsp. citri
}

Laís Moreira Granato ${ }^{1,2}$, Simone Cristina Picchi ${ }^{1}$, Maxuel de Oliveira Andrade ${ }^{3}$, Marco Aurélio Takita', Alessandra Alves de Souza', Nian Wang ${ }^{3}$ and Marcos Antonio Machado ${ }^{1 *}$ (D)

\begin{abstract}
Background: RNA helicases are enzymes that catalyze the separation of double-stranded RNA (dsRNA) using the free energy of ATP binding and hydrolysis. DEAD/DEAH families participate in many different aspects of RNA metabolism, including RNA synthesis, RNA folding, RNA-RNA interactions, RNA localization and RNA degradation. Several important bacterial DEAD/DEAH-box RNA helicases have been extensively studied. In this study, we characterize the ATP-dependent RNA helicase encoded by the hrpB (XAC0293) gene using deletion and genetic complementation assays. We provide insights into the function of the hrpB gene in Xanthomonas citri subsp. citri by investigating the roles of $h r p B$ in biofilm formation on abiotic surfaces and host leaves, cell motility, host virulence of the citrus canker bacterium and growth in planta.

Results: The hrpB gene is highly conserved in the sequenced strains of Xanthomonas. Mutation of the hrpB gene ( $\triangle$ hrpB) resulted in a significant reduction in biofilms on abiotic surfaces and host leaves. $\Delta$ hrpB also exhibited increased cell dispersion on solid medium plates. $\triangle$ hrpB showed reduced adhesion on biotic and abiotic surfaces and delayed development in disease symptoms when sprayed on susceptible citrus leaves. Quantitative reverse transcription-PCR assays indicated that deletion of $h r p B$ reduced the expression of four type IV pili genes. The transcriptional start site of fimA (XAC3241) was determined using rapid amplification of 5'-CDNA Ends (5'RACE). Based on the results of fimA mRNA structure predictions, the fimA 5' UTR may contain three different loops. HrpB may be involved in alterations to the structure of fimA mRNA that promote the stability of fimA RNA.
\end{abstract}

Conclusions: Our data show that hrpB is involved in adherence of Xanthomonas citri subsp. citri to different surfaces. In addition, to the best of our knowledge, this is the first time that a DEAH RNA helicase has been implicated in the regulation of type IV pili in Xanthomonas.

Keywords: RNA helicase, Xanthomonas citri, Biofilm, Citrus canker, Type IV pili

\footnotetext{
*Correspondence: marcos@centrodecitricultura.br

${ }^{1}$ Centro de Citricultura Sylvio Moreira/IAC, Rodovia Anhanguera Km 158,

Cordeirópolis, SP 13490-970, Brazil

Full list of author information is available at the end of the article
} 


\section{Background}

RNA helicases are enzymes that catalyze the ATPdependent separation of double-stranded RNA (dsRNA). RNA helicases are found in all kingdoms of life $[1,2]$. DEAD-box proteins, which are named for their highly conserved motif I residues (Asp-Glu-Ala-Asp), and the related DEAH, DExH and DExD families, which are commonly referred to collectively as the $\mathrm{DExD} / \mathrm{H}$ helicase family, share eight conserved motifs [3-5] that have been shown to be involved in the activities and regulation of ATPases and helicases [6].

$\mathrm{DExD} / \mathrm{H}$ proteins participate in many different parts of RNA metabolism, including RNA synthesis, RNA folding, RNA-RNA interactions, RNA localization and RNA degradation [6-9]. Several bacterial DEAD/DEAHbox proteins have been characterized and found to be involved in different phenotypes. For example, in Bacillus subtilis, two cold-induced putative RNA-helicases, CshA and CshB, are thought to be essential for cold adaption, during which they work in conjunction with cold-shock proteins to rescue misfolded mRNA molecules and to maintain proper initiation of translation at low temperatures [10]. Mutation of the $\operatorname{csh} A$ DEAD-box gene in Staphylococcus aureus resulted in the dysregulation of biofilm formation and hemolysis via modulation of agr mRNA stability [6]. Furthermore, the putative DEAD-box helicase AggH is important during autoaggregation [11] in Lactobacillus reuteri. In Listeria monocytogenes, four putative DEAD-box RNA helicases (lmo0866, lmo1246, lmo1450 and lmo1722) are required for growth and motility [12].

HrpA, a DEAH-box RNA helicase in Escherichia coli, is involved in processing daa mRNA from a fimbrial operon. This processing event results in a stable mRNA and the up-regulation of daa expression relative to the levels of other proteins that are encoded by the polycistronic transcript [13]. The HrpA protein also appears to be involved in physical interactions with a variety of ribosomal proteins in E. coli either directly or indirectly through RNA interactions [14, 15], consistent with a possible translational-level regulatory role [8].

In our previous study, we screened Xanthomonas citri subsp. citri ( $X$. citri) for mutants that were associated with effects on biofilm and identified hrpB (XAC0293), which encodes a probable DEAHbox RNA helicase. The function of RNA helicases in the Gram negative bacteria $X$. citri has not been explored. $X$. citri causes citrus canker, one of the most economically damaging diseases that affects citrus $[16,17]$. It is spread by wind-blown rain and invades the host directly through natural openings, such as stomata, and through wounds [16]. Previous studies have shown that $X$. citri forms biofilms on leaf surface [18-21], which increases the epiphytic survival of the bacteria and plays an important role in the invasion of host intercellular spaces by $X$. citri $[18,22]$.

Biofilms are communities of bacterial cells that are embedded in a matrix of extracellular polymeric compounds that are attached to a surface [23]. Biofilm formation is a dynamic and complex process that generally includes the initial attachment of cells to the surface at the substratum, physiological changes within the organism, multiplication of the cells to form microcolonies and the maturation of the biofilm [21]. The stable adhesion of the bacteria to the surface is a key step in biofilm formation, and type IV pili (T4P) genes are thought to be important for cell-to-cell aggregation and adherence to surfaces [24]. The $X$. citri strain 306 contains a functional T4P [25]. The FimA proteins (XAC3241 and XAC3240), which form the major pilin subunit [26], are produced through the secretion and polymerization of pilin subunits via a process that depends on PilB, a hexameric ATPase that is associated with the bacterial inner membrane [27]. Pilus retraction is powered by another ATPase, PilT/PilU [28].

In this study, we showed that the hrpB (XAC0293) gene plays an important role in adherence and biofilm development in $X$. citri and that its deletion reduced the expression of type IV pili genes. Our study sheds light on the involvement of DEAH-box proteins in adhesion, biofilm formation and pathogenicity in plant-pathogen bacteria.

\section{Results}

XAC0293/hrpB encodes a putative ATP-dependent RNA helicase that is involved in RNA metabolism

The XAC0293 open reading frame (ORF) is 2501 bp in length and is located within the genome at position 348799-351300 (Fig. 1). The adjacent genes upstream (XAC0294) and downstream (XAC0292) of this location are in the same orientation and encode hypothetical proteins. XAC0293 was annotated as an 833 amino acidlong ATP-dependent RNA helicase, and the predicted pI and molecular weight (MW) of this amino acid are 9.49 and $90.9 \mathrm{kD}$ (http://web.expasy.org/compute_pi/), respectively. The protein XAC0293 shares $42 \%$ identity with the Escherichia coli RNA helicase HrpB, the function of which has not been described. A domain structure analysis performed using the Pfam database showed that XAC0293 contains four domains that are associated with DEAD/H-box RNA helicase proteins, including a DEAD-like helicase superfamily domain (DEXDc) at the $\mathrm{N}$-terminal, a helicase superfamily c-terminal domain (HELICc), a helicase-associated domain (HA2), and an ATP-dependent helicase C-terminal domain (HrpB_c) at its C-terminal. The HrpB protein also contains two predicted ATP-binding sites, one $\mathrm{Mg}^{++}$-binding site and one nucleotide-binding region. Protein BLAST showed 


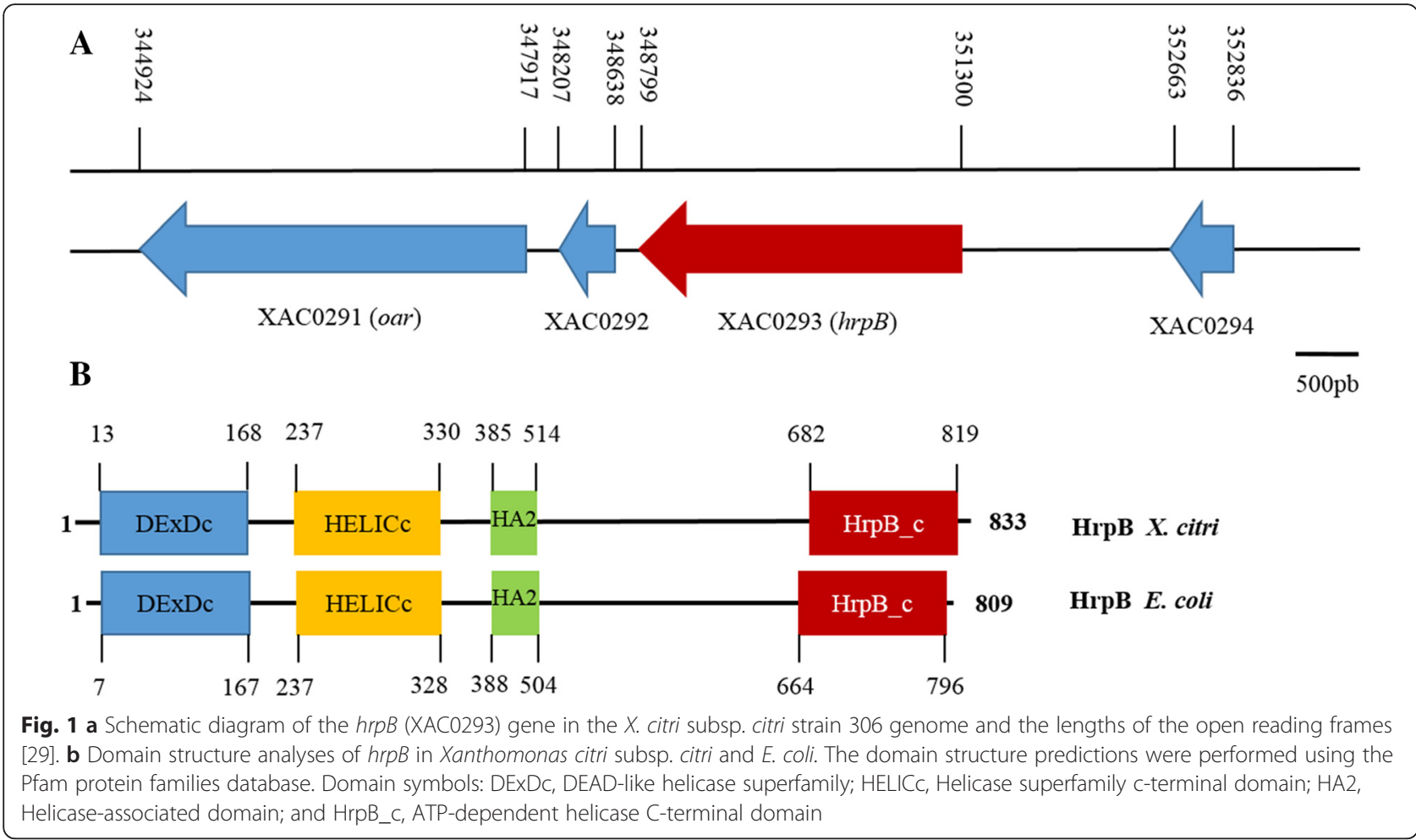

that XAC0293 is highly conserved in other Xanthomonas species (Fig. 2), including $X$. campestris pv. vesicatoria str. $85-10$ (97\% identity), X. oryzae pv. oryzae KACC 10331 (95\% identity), X. campestris pv. campestris str. ATCC 33913 (91 \% identity), and Xylella fastidiosa (72\% identity) (Table 1$)$. In addition, a total of four ATP-dependent RNA helicases were identified in $X$. citri, including Xac0293, Xac3122, Xac2390, and Xac0442. Among these, both Xac0293 and Xac0442 are DEAD-box helicases.

\section{Mutation of $h r p B$ affected biofilm formation on abiotic surfaces and host leaves in $X$. citri}

To study the function of $h r p B$, we used an allelic exchange protocol to produce an $h r p B$ mutant $(\triangle h r p B)$ of $X$. citri strain 306, which was confirmed using PCR. The growth curve of the mutant was not different from that in the wild-type (data not shown). Biofilm development was examined in polystyrene plates and glass tubes and on sweet orange leaves. A significant reduction in biofilm formation was observed in $\triangle h r p B$ after $48 \mathrm{~h}$ of growth in NB medium containing $1 \%$ glucose compared to the wild-type and complemented strains (Fig. 3a). Crystal violet staining was over 5 times more intense in the $X$. citri wild-type strain than in the $\triangle h r p B$ strain. Similar results were observed in attachment to abiotic and leaf surfaces. The $\Delta h r p B$ strain formed over 4 times less biofilm on host leaves $(\mathrm{OD} 590=0.54 \pm 0.20)$ than the wild-type strain $(O D 590=2.19 \pm 0.45)$, and the complemented strain, $\Delta h r p B-p 53 h r p B$, formed levels similar to the wild-type strain (Fig. 3b). No difference was observed in xanthan gum production between the wild-type and mutant $h r p B$ strains under the tested conditions (data not shown). These findings suggest that the $h r p B$ gene is involved in cell adhesion and, consequently, biofilm formation in $X$. citri.

Deletion of $X A C 0293 / h r p B$ resulted in increased motility RNA helicases have previously been reported to be involved in bacterial motility $[12,30]$. The $\triangle h r p B$ and wildtype strains were both tested to determine their motility on $0.5 \%$ agar SB medium, which is used in sliding analyses in $X$. citri. In $X$. citri, sliding motility was promoted by EPS and inhibited by type IV pili [19, 27]. Deletion of $h r p B$ increased cell dispersion in $X$. citri on SB medium plates ( $P<0.05$, turkey test) (Fig. 4a). On the plate, the diameters of the growth zones that resulted from migration away from the inoculation points on the agar surface were approximately $1.41 \mathrm{~cm}$ for $\triangle h r p B$ and $0.61 \mathrm{~cm}$ for the wildtype strain after $48 \mathrm{~h}$ at $28{ }^{\circ} \mathrm{C}$ (Fig. 4b). Swimming analyses were also performed, but no difference was observed between the mutant and wild-type strains (data not shown). The complemented strain showed results similar to those of the wild-type strain, indicating that the motility phenotype of the mutant was restored (Fig. 4a and b). Growth curve assays were performed, and no difference was observed between the strains, indicating that the difference observed in the motility assays was not related to growth. 


\section{Xoitri \\ Xvesicatoria Xoryzae \\ Xcampestris xfastidiosa Eooli}

Xoitri

Xvesicatoria

Xoryzae

Xcampestris

xfastidiosa

Ecoli

Xoitri

Xvesicatoria

Xoryzae

Xcampestris

Xfastidiosa

Ecoli

Xoitri

Xvesicatoria

Xoryzae

Xcampestris

xfastidiosa

Ecoli

Xoitri

Xvesicatoria

Xoryzae

Xcampestris

xfastidiosa

Ecoli

Xoitri

Xvesicatoria

Xoryzae

Xcampestris

xfastidiosa

Ecoli

Xoitri

Xvesicatoria

Xoryzae

Xcampestris

Xfastidiosa

Ecoli

Xoitri

Xvesicatoria

Xoryzae

Xcampestris

xfastidiosa

Eooli

Xoitri

Xvesicatoria

Xoryzae

Xcampestris

xfastidiosa

Ecoli
EAPFGAGKTTO VPLALLDAPWIAGRKIVMLEPRRVAARSAAOFMAROLGEPVGETVGYRI 87 EAPFGAGKTTQVPLALLDAPWLAGRRI VMLEPRRVAARSAAQFMARQLGEPVGETVGYRI 120 EAP F GAGKTT QVPLAL.L.RAPWLAGRK I VMLEPRRVAARSAAQFMARQLGEPVGEMVGYRI 77 BAPFGAGKTTOVPLALLIDAPWIAAGS IVMLEPRRVAARSAALFMAROLGEPVGETVGYRI 90 EAPF GAGKTTQ VPLALLLDAPWLNGRS I ILLEPRRVAARNAALFMARQCGEEVGGLVGYHI 87 SAPTIAGKSTWLPLQLLLAHPGING-KI ILLEPRRLAARNVAQRLAAELLNEKPGDTVGYRM 84

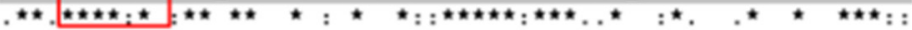

RFENKTSARTRIEVVTEGILTRLIQDD PMLLESVGVLLLFDEFHERHIAGDLGLALANDVVA 147 RFENKTSARTRIEVVTEGILTRLIQDD PML.ESVGALLLFDEFHERHI_AGDLGLALAILDVOA 180 RPEKTSARTRIEVVTEGI LTRLI IDDPMLDSVGVLLFDEFHERHLAGDLGLALALDVQSN 137 RFENKTSARTRIEVVTEG ILTRMLQDDPMLERVGALLLFDEFHERHLAGDLGLALALDVQS 150 RFESKVSARTRI QVVTEGILTRI IQDDPLLDGIGALLLFDEFHERHIASDLGGLALALDVQT 147 RAQNCVGPNTRLEVVTEGVLTRMIQRDPELSGVGLVILDEFHERSLOADLALALLLDVQQ 144

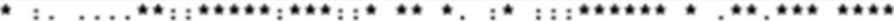

QVRDDLRIVAMSATLDGERLAGFL-EAPRLSSAGRSFPVE IAHFPARRDEALEPQTRRAV 206 QVRDDLRIVAMSATLDGERLAGFL-EAPRLSSAGRSFPVE IAKFPARRDEALEPQTRRAV 239 QVREDLRIVAMSATLDGERLAGFL-EAPRLSSAGRSFPVE IAHFPARRDEALEPQTRRAV 196 QVREDLRIVAMSATLDGERLASFL-DAPRLSSAGRSYPVEVAHFPARRDEALEPQTRRAV 209 QLREDLRIVVMSATLQGERLAQFL-DAPRLTSEGRAYPVAITHFPARRDESLETHARRAI 206 GLRDDLKLLIMSATLDNDRLQQMLPEAPVVI SEGRSFPVERRYPLPAHQRPDDAVAVAT 204

$$
: \star: \star \star::: \star \star \star \star \star \star::: \star \star \quad: \star: \star \star: \star \star \star \star:: \star \star \quad:: \star \quad:::: \quad . \quad *
$$

RRRVVLATNVAESSVTLPGVRVVIDSGLAREPHYDPNSGFSRLDVAAIAOASADORAGRA 326 RRRVVLATNVAESSVTLPGVRVVIDSGLAREPHYD PNSGFSRLDVAAIAQASAEQRAGRA 359 RRRVVI_ATNVAESSVTLPGVRVVIDSGLAREPHYDPNSGPSRLDVAAIAQASADQRAGRA 316 RRRVVLATNVAESSVTLPGVRVVIDSGLAREPHYDPNSGFSRLDVTSIAQASADQRAGRA 329 RQRIVL.ATNVAESS I TL.PGI SVVIDSGLAREPAYD PNTGFTRLDVVS I TQASADQRAGRA 326 MRKVVLATNIAETSLTIEGIRLVVDCAQERVARFDPRTGLTRLITORVSOASMTORAGRA 324

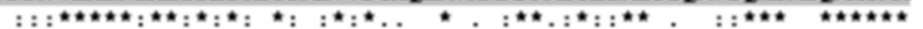

ALAAAHRLLORLGALTASGGITALGRPMIIALGTHPRLANMILAOAGEATRVAIACDIAALLL 441 ALAAARELLRRLGALTASGGITTLGRPMLALGTHPRLAAMILAOAGDAPRVALACDLAALL 474 ALAAAHALLORLGALTASGG ITALGRPMLALGTHPRLAAMLAQAGDAPRVALACDLAALL 431

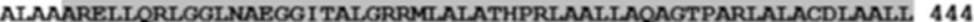
ALSAARELLLRLGAI SNTSTLTPLGQRMI_ALGIHPRL_AAMLLIAPHDPQEQALACDLAALL 441 NLIAAKRLLOMLGALEGE-RLSAQGQKMAALGNDPRLAAMLVSAKNDDEAATAAKIAAIL 443

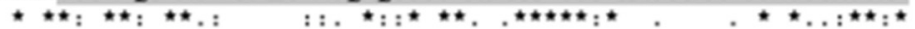

EARDPLLRQGDGLAARWRALAAFRQGRSAADANRGGLAAIDSAARQWRRRLRCDSVPPSS 501 EARDPLRQGGDGLANRWRALAAFROGRSAADADRGGLAMIDSANKOWRRRLRCDSAPPSS 534 EARDPLRQGGDGLAARWRALAAFRHGRSAADANRGGLAAIDSAAKQWRRRLRCDSAPPSS 491 EARHPLRQGGDGLAARWRALAAARQGRTGADANRGALAAIDAAAKQWRRRLRCDATPPTS 504 DARDPLRGSGDAL I SRWRAL_AELRSSCL_PHDTRRSTLLRAIDAATHQWRRRIRCDTTPPDA 501 EE--PPRMGNSDLG------VAFSRNQ----------PAWQQRSQQLLKRLLNVRGG---E 482

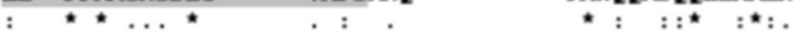

DTWLRPAFAGKTRLDAL.DEASLGEAL.KSALPWERRQS IDRHAPTRISVPSGMERPISYAL 739 DTWL.RPAFAGKTRLDALDEASLGEALLKSALPWERRQWIDRHAPTRISVPSGMERPISYAL 772 DSWLRPAFAGKTRLDALDEASLGEALKAALPWERROAIDRHAPTRISVPSGMEROISYAL 729 DHWL.RPAFAGKTRLDAL.DEASLGDAL.KANL.PWERROAIDRHAPTRI SVPSGMERAITYAL 742 DTWLTPAFAGKTRLDALDEAAFEQAVKSLLSWTQHAL IDRHAPARI IVPSGMERHIDYGL 739 ETWLLPFMTGVHSLRGLKSLDIYOALRGLLDWGMOQRLDSELPAHYTVPTGSRIAIRYHE 721

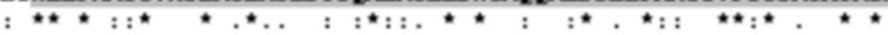

DHAGQPLPPVLAVKLOEL_FGLAETPRIADGRIPLTLLHLLSPGGRPQVTODLKSFWATTY 799 DHAGQPLPPVLAVKLQELFGLAETPRIADGRIRLTLHLLSPGGPPQVTQDLKSFWANTY 832 DHTGQPLPPVLAVKLOELFFLAATPRIADDRILLTLLHLLSPGGHPLQVTQDLKSFWANTY 789 DHDQOPLPPVI_AVKLOEL_FGLAETPRVADGRI PLTLLHLLSPGGRPLOVTODI.KSCWATTY 802 ADDGTPQPPVLAVKLQELFGLPDTPRIAKNRI PLTLHLLSPGGRPLVTQDLKSFWTNTY 799 DN-----PPALAVRMQEMFGEATNPTIAQGRVPLVLELLSPAQRPLQITRDLSDFWKGAY 776

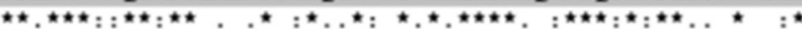

PDVKKEMTKGRYPRHPWPDDPWTAAATHRAKPRGT 833 PDVKKEMMKGRYPRHPWPDD PWTAAATHRAKPRGT 866 PDVKKEMKKGRYPRHPWPDDPWTAAATHRAKPRGT 823 PDVKKEMMKGRYPRHPWPDDPWTANATHRAKPRGT 836 PEVKKEMKGRYPKHPWPDDPWTATATHRTKSPGK 833 REVQKEMKGRYPKHVWPDDPANTAPTRRTKKYS- 809

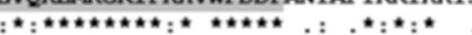

Fig. 2 Sequence alignments of HrpB homologs. The * indicates the presence of a conserved motif. The ATP-binding region (GAGKT) that characterizes the DEAD-like helicase superfamily is indicated by a box. Abbreviations are as follows: ECHrpB, Escherichia coli str. K-12 str. DH10B; Xf1229, Xylella fastidiosa 9a5c; Xcc0275, Xanthomonas campestris pv. campestris str. ATCC 33913; Xoo4533, Xanthomonas oryzae pv. oryzae KACC 10331; Xac0293, Xanthomonas citri subsp. citri; and Xcv0300, Xanthomonas campestris pv. vesicatoria str. 85-10 
Table 1 Protein alignments of Xanthomonas citri subsp. citri in different bacteria

\begin{tabular}{llcc}
\hline Strains & Proteins & XAC0293 (hrpB) & E-value \\
\hline Xanthomonas campestris pv. vesicatoria str. 85-10 & & 0.0 & $97 \%$ \\
Xanthomonas oryzae pv. oryzae KACC 10331 & ATP-dependent helicase HrpB & 0.0 & $95 \%$ \\
Xanthomonas campestris pv. campestris str. ATCC 33913 & ATP-dependent RNA helicase & 0.0 & 0.0 \\
Xylella fastidiosa 9a5C & ATP-dependent RNA helicase & 0.0 & $72 \%$ \\
Escherichia coli str. K-12 substr. DH10B & ATP-dependent helicase & $42 \%$ \\
\hline
\end{tabular}

\section{HrpB is important to $X$. citri survival on host leaves and contributes to virulence}

The data from the motility and biofilm formation assays together indicated that there was a reduction in adhesion that could lead to decreased survival in $X$. citri on its sweet orange host. Populations of different strains were quantified at different post-spraying time points on citrus leaf surfaces. At seven days after the initial inoculation, the $\triangle h r p B$ population was smaller than the population of the wild-type strain 306 (Fig. 5b). Delayed symptoms were observed in the $\triangle h r p B$ strain compared to the wild-type strain. At 21 days post-inoculation (dpi), the number of canker lesions on leaves infected with $\triangle h r p B$ was significantly less than the number on leaves inoculated with the wild-type strain (Fig. 5a). Symptoms induced by $\triangle h r p B$ could be restored to wildtype levels by complementation with plasmid-borne hrpB (Fig. 5b). However, there was no difference between the wild-type and the $\Delta h r p B$ strains in growth or symptom development when they were inoculated into the host leaves via infiltration using a low concentration of bacteria (Additional file 1: Figure S1). These findings suggest that $h r p B$ plays an important role in the initial stages of infection in leaves, probably before entry of the pathogen into host plant intercellular spaces.

\section{HrpB regulates the expression of type IV pili (T4P) genes} To gain new insights into the roles of $h r p B$ in biofilm formation and to explain the reduction observed in adherence in the $h r p B$ mutant, we performed qRT-PCR assays using total RNA from wild-type and $\triangle h r p B$ strains that were grown in NB medium and in orange leaves that were inoculated by spraying. We determined the expression levels of four type IV pili genes (T4P) based on our results and previous studies that showed that mutations in type IV pilus gene are associated with increased

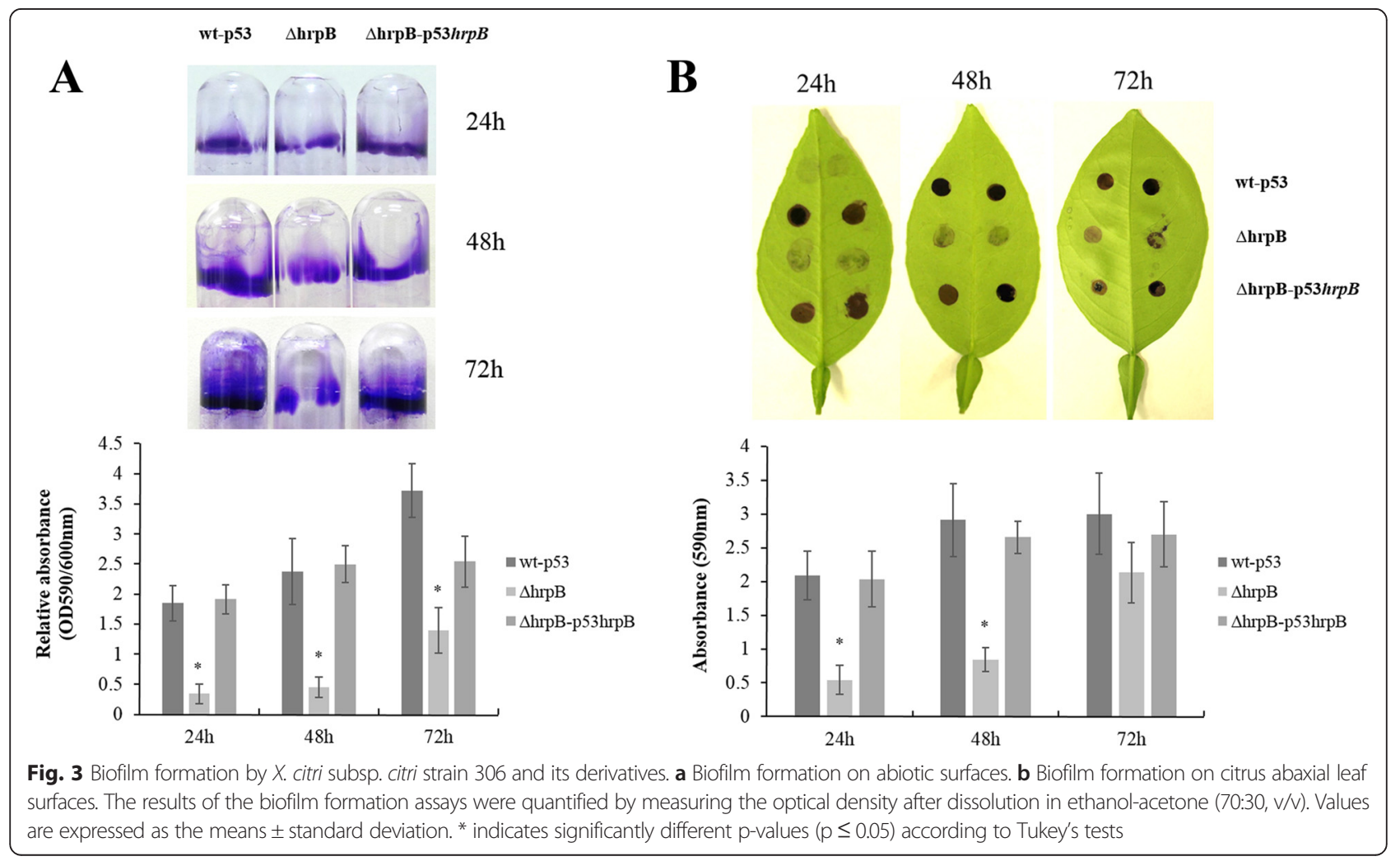




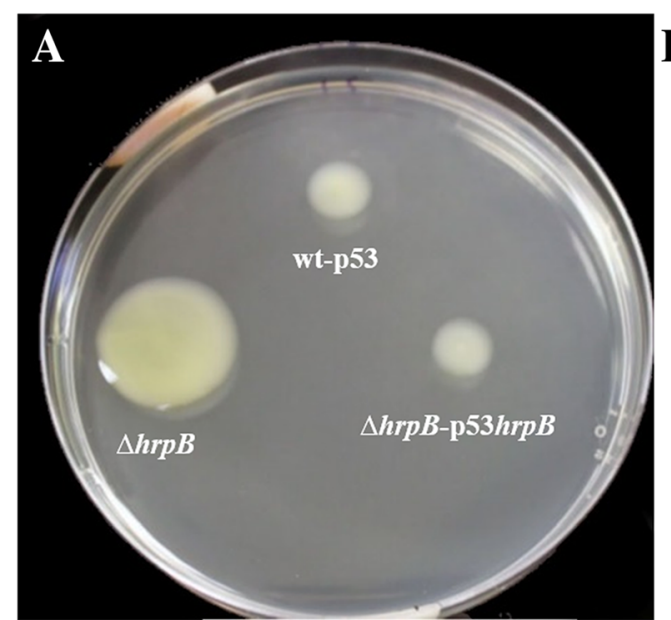

B

Fig. 4 Sliding motility in $X$. citri subsp. citri strains. a $\triangle$ hrpB showed an increase in motility that could be restored to wild-type levels by the introduction of a plasmid containing the intact hrpB gene. $\mathbf{b}$ Measurements of the diameters of cell spread on plates. Cells were inoculated from bacterial cultures at exponential stage onto SB plates that were supplemented with $0.50 \%$ agar. The assays were photographed and measured after $48 \mathrm{~h}$ of incubation at $28^{\circ} \mathrm{C}$. Abbreviations: wt-p53, wild-type strain 306 with empty vector pUFR053; $\triangle$ hrpB, hrpB mutant; and $\triangle$ hrpB-p53hrpB, complemented hrpB mutant. Values are expressed as the means \pm standard deviations of three independent experiments. Different letters indicate significantly different $p$-values $(p \leq 0.05)$ in Tukey's tests

motility and decreased biofilms [26, 27]. The genes fim $A_{\mathrm{XAC} 3241}$ and fimA2 $2_{\mathrm{XAC} 3240}$, which encode for the major pilin subunit [26], and pilB $\mathrm{XAC3239}_{\text {, an ATPase }}$ gene that is required for T4P polymerization [27], may belong to the same operon that exhibited lower expression levels in the $\triangle h r p B$ strain than in the wild-type strain on NB medium (Fig. 6a). On the other hand, the expression of pil $T_{\mathrm{XAC} 2924}$, an ATPase that is essential for T4P biogenesis [31], was not different from that observed in the wild-type (Fig. 6a). Likewise, qRT-PCR results from an analysis of X. citri recovered from leaves showed that there were no changes in the expression of the studied genes between $\triangle h r p B$ and the wild-type strain at $1 \mathrm{dpi}$. However, as shown in Fig. $6 \mathrm{~b}$, at 3 and $7 \mathrm{dpi}$, the expression levels of fimA, fimA2 and pilB were reduced in the $\triangle h r p B$ strain compared to the wild-type strain. Analysis of the results from qRT-PCR
A

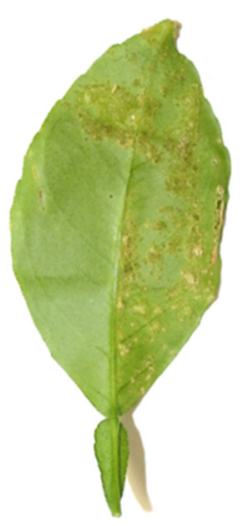

wt-p53

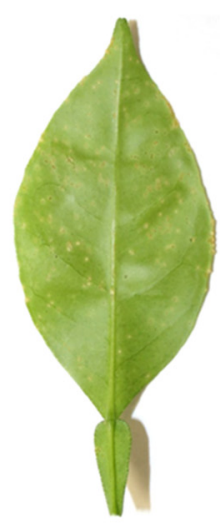

$\triangle \boldsymbol{h r p B}$

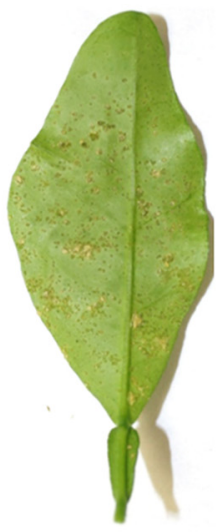

$\Delta h r p B-p 53 h r p B$
B

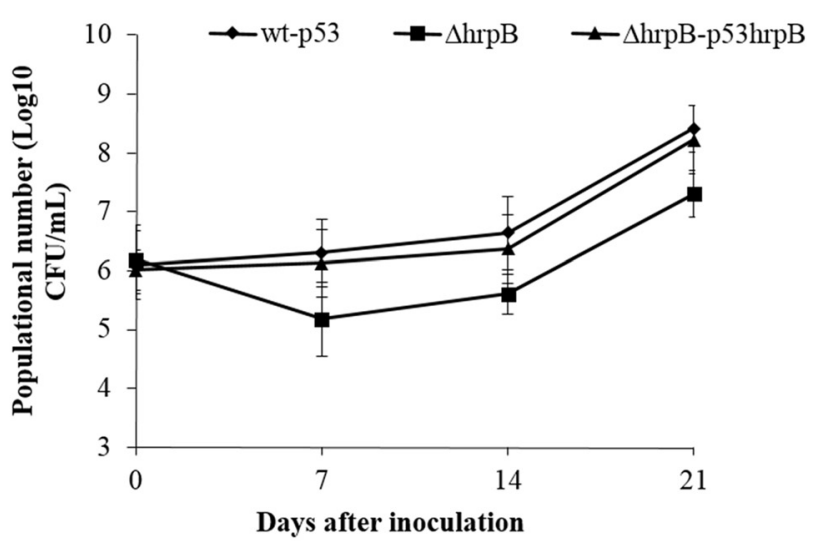

Fig. 5 Pathogenicity assay and growth of $X$. citri subsp. citri strains in planta. a Symptoms were analyzed on the lower the surfaces of sweet orange leaves at 21 days post-inoculation (d.p.i.). b In vivo bacterial growth in populations of wild-type, $\triangle$ hrpB and a complementary strain of Xanthomonas citri subsp. citri (X. citri) that were inoculated on the sweet orange leaves by spraying the leaves with bacteria at a concentration of $10^{8} \mathrm{CFU} / \mathrm{mL}$. Bacterial cells were extracted from the leaves at different time points after inoculation. The leaves were homogenized in $\mathrm{MgCl}_{2}$ and then plated on appropriate media after serial dilution. Colonies were counted after a 2-day incubation at $28^{\circ} \mathrm{C}$. Abbreviations: wt-p53, wild-type strain 306 with empty vector pUFR053; $\triangle$ hrpB, hrpB mutant; and $\triangle$ hrpB-p53hrpB, complemented hrpB mutant. Values are expressed as the means \pm standard deviations of three independent experiments 

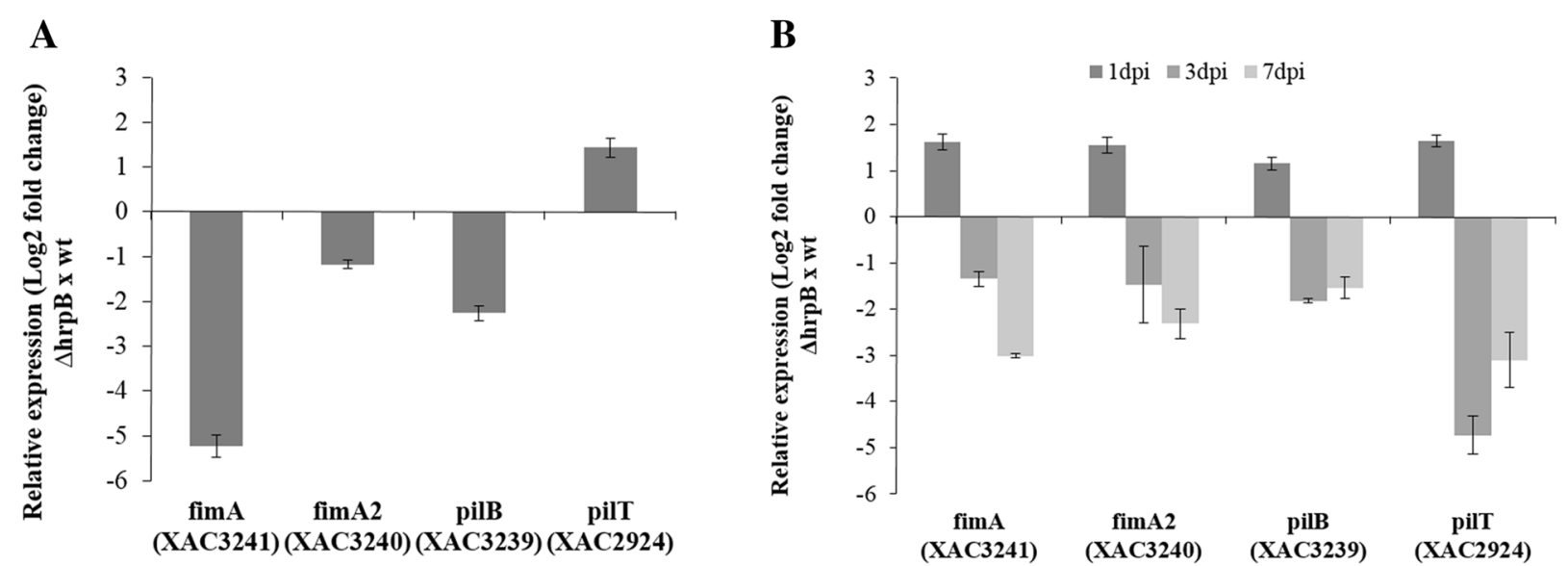

Fig. 6 Comparison of type IV pili gene expression (using qRT-PCR) in the wild-type and the $\triangle$ hrpB bacteria that were cultured in NB medium and in planta. a Relative expression levels on NB medium. $\mathbf{b}$ Relative expression levels in planta. The data are presented as the ratio (Log 2 -fold change) of the transcript number in $\triangle h r p B$ compared to the number in wild-type. The DNA gyrase subunit A-encoding gene gyrA was used as an endogenous control. Both qRT-PCR assays were repeated twice with similar results, and three independent biological replicates were performed each time

suggested that the $\triangle h r p B$ phenotype reflects the impaired expression of $\operatorname{fim} A$, fimA2, and pilB, which encode the essential components of the type IV pili machinery.

\section{Mapping of the $5^{\prime}$ untranslated region of the fimA (XAC3241) transcript}

Previous studies have suggested that RNA helicases act by unwinding the secondary structure of the $5^{\prime}$ UTR in the target mRNA, which enables binding and scanning by the small ribosomal subunit to the start codon, AUG $[1,2]$. To determine the mechanism by which HrpB acts on the fimA transcript, we mapped the 5'-UTR of the fimA mRNA to check the presence of putative secondary structures in this region. The $5^{\prime}$ UTR of fimA was determined using rapid amplification of $5^{\prime}$-cDNA ends ( $5^{\prime}$ RACE). The RACE PCR product was sequenced to identify the specific transcriptional start site of fimA, which is located 113 nucleotides upstream of the first codon (Fig. 7a). Analysis of the 5' RACE results showed that the -35 and -10 regions were the locations for the ribosome binding site and the first codon for fim $A_{\mathrm{XAC} 3241}$ in $X$. citri (Fig. 7b). Mfold [32] was used to predict the RNA structure of this region, and the analysis suggested that the fimA 5' UTR may contain three different loops (Fig. 8a).

\section{Effects of hrpB on fimA transcript stability}

Because the qRT-PCR analysis showed that there were lower levels of the transcripts of the fimA, fimA2 and pilB genes in $\triangle h r p B$ cells that were grown in rich medium and on plant surfaces, we next analyzed the stability of the fimA (XAC3241) transcript in the wild-type and $\triangle h r p B$ strains. To measure the stability of the fimA
mRNA in the wild-type and $\triangle h r p B$ strains, the abundance of the fim $A$ transcript was analyzed using the $g y r A$ transcript as a control in RT-PCR. Prior to the reactions, transcription was blocked by adding $10 \mu \mathrm{g} / \mathrm{mL}$ ciprofloxacin (Sigma, USA) to the $X$. citri cell cultures. The relative abundance of the fimA transcripts was estimated from the specific PCR products that were observed on the agarose gels in comparison to the abundance of the control. The data showed that there was a significant reduction in the abundance of the fimA mRNA after 10 and $15 \mathrm{~min}$ in $\triangle h r p B$ compared to the wild-type strain (Fig. 8b). These results revealed that the fimA transcript may be more stable in wild-type $X$. citri strains than in the $h r p B$ mutant. This reduced stability may contribute to the differences observed in fim $A$ transcript levels between the $\triangle h r p B$ and the wild-type $X$. citri strains in the qRT-PCR experiments (Fig. 6).

\section{Discussion}

Stable adhesion to an appropriate surface is the first step in biofilm formation [33]. The ability of $X$. citri to form biofilms enhances the epiphytic persistence of this species on host leaves, which plays an important role in the early stages of infection $[18,21]$. The present study indicates that a putative DEAH-box ATP-dependent RNA helicase, HrpB, may perform many roles in X. citri because it is important for adherence to surfaces and motility and for the epiphytic survival of the bacteria on citrus leaves, which results in a reduction in the development of symptoms. The phenotype changes observed in $\triangle h r p B$ may be caused by the positive regulation of T4P genes, such as fimA (XAC3241), by the HrpB protein in wild-type $X$. citri. Our results show that the predicted HrpB protein in $X$. citri exhibits several characteristics 


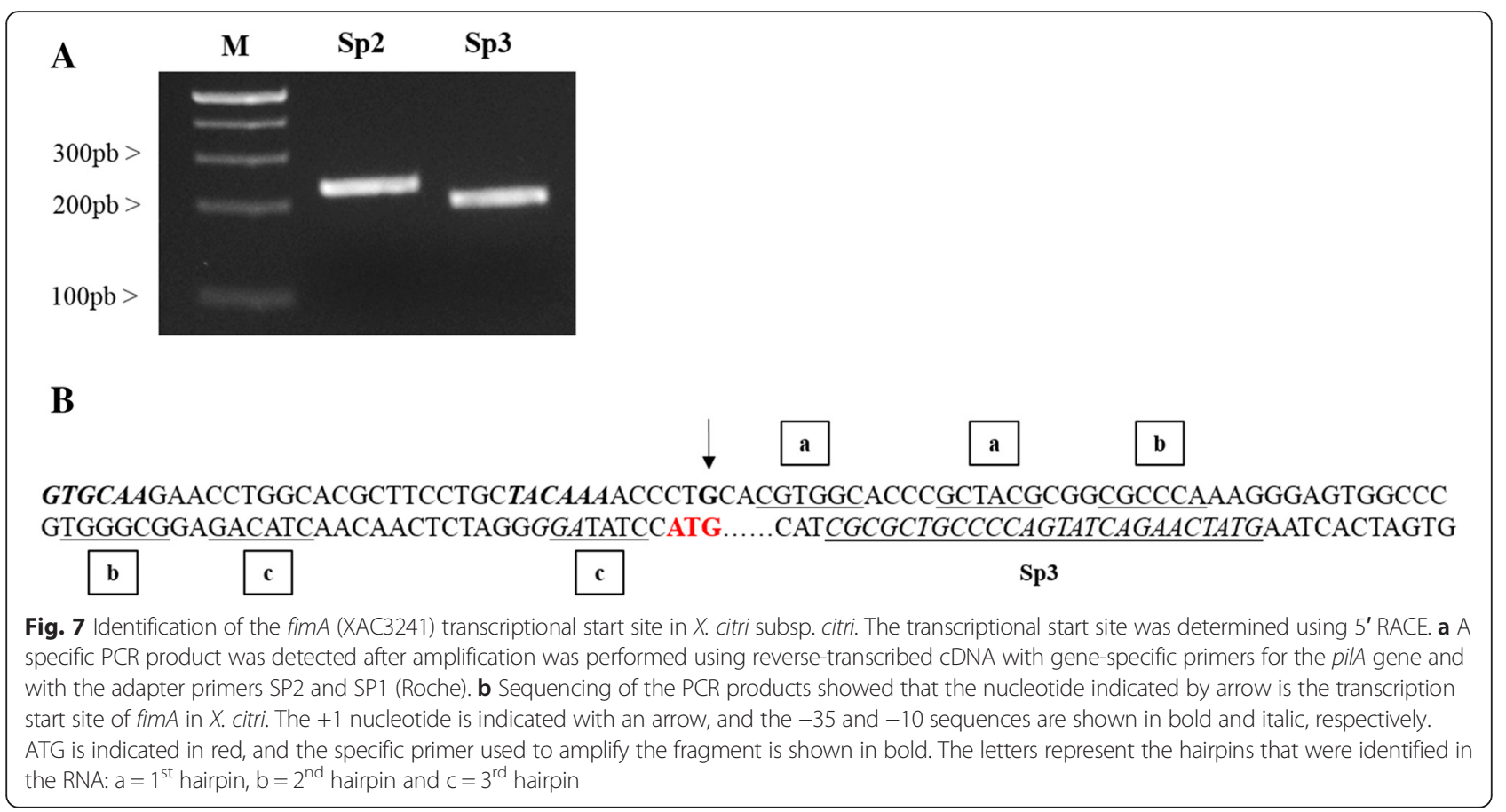

that are considered typical for RNA helicases [2, 4]. These include a DEAH-like helicase superfamily domain and the presence of an ATP-binding region (GAGKT) (Fig. 1). Previous studies have suggested that DExD/Hbox RNA helicases may be essential to these processes [34]. The observed $h r p B$ mutants may be caused by the presence of multiple DEAD-box RNA helicases in $X$. citri, such as Xac0293 and Xac0442. Interestingly, four DEAD-box helicases, SrmB, RhlE, CsdA, and RhlB, are present in E.coli, and RhlB, RhlE, and CsdA are interchangeable for certain functions [35].

In plant-bacteria interactions, biofilm formation has been implicated in the virulence of several bacterial pathogens [36], including $X$. citri $[18,21,37,38]$. Different genes have been found to be important for biofilm formation in $X$. citri $[20,21,33,38-40]$. However, to the best of our knowledge, $h r p B$ (XAC0293) has not been previously reported to play a role in biofilm formation in Xanthomonas. In $X$. citri, deletion of $h r p B$ resulted in a decrease in cell adhesion and consequently less biofilm compared to a wild-type strain on both abiotic and biotic surfaces (Fig. 3). The $\triangle h r p B$ mutant also showed a reduction in population on leaf surfaces when spray inoculated and a delay in canker development (Fig. 5). Similar phenotypes were also observed in other X. citri mutants, including type 4 pilus mutants $[18,41]$. As expected, no difference was observed in symptoms when the $h r p B$ mutant cells infiltrated into the host the leaves (Additional file 1: Figure S1). Similar results were previously reported in $X$. citri T4P mutants, indicating that T4P plays an important role in the adherence and epiphytic stages of canker disease but not in the mesophyll stage, whereas other mechanisms, such as the type III secretion system, have been shown to be involved [26]. The reduction in adhesion was also observed as a significant increase in sliding motility on a semisolid medium (Fig. 4). The faster movement of the cells may be attributed to a lack of cell-to-cell aggregation. A similar phenotype was observed in X. citri when the hemagglutinin-like adhesins that are involved in cell-tocell aggregation were mutated [33]. In addition, it has been shown that in $X$. citri, sliding motility is inhibited by surface structures, such as T4P, possibly as a result of the increased interactions between the bacterial cells and the substrate $[19,21,27,41]$. Therefore, fim $A$ (XAC3241) and pilB (XAC3239) mutants showed increased sliding motility and reduced biofilm formation $[26,27]$. Taken together, these results are in agreement with our data, in which we verified that $h r p B$ mutation resulted in the repression of TP4 genes, a reduction in adhesion and an increase in movement (Fig. 6).

RNA helicases participate in many aspects of RNA metabolism and have been shown to be involved in different phenotypes, including phenolic acid metabolism [42], cold adaption [10], auto-aggregation [11], motility [30] and biofilm formation [43]. One of the main functions of DEAD/DEAH-box RNA helicases is the binding and remodeling of the secondary structures of RNA molecules. Our results show that the fimA 5' UTR contains three different loops in its structure. These loops could impair the initiation of translation in $X$. citri cells (Fig. 7). Studies of mRNA regulation have shown that 


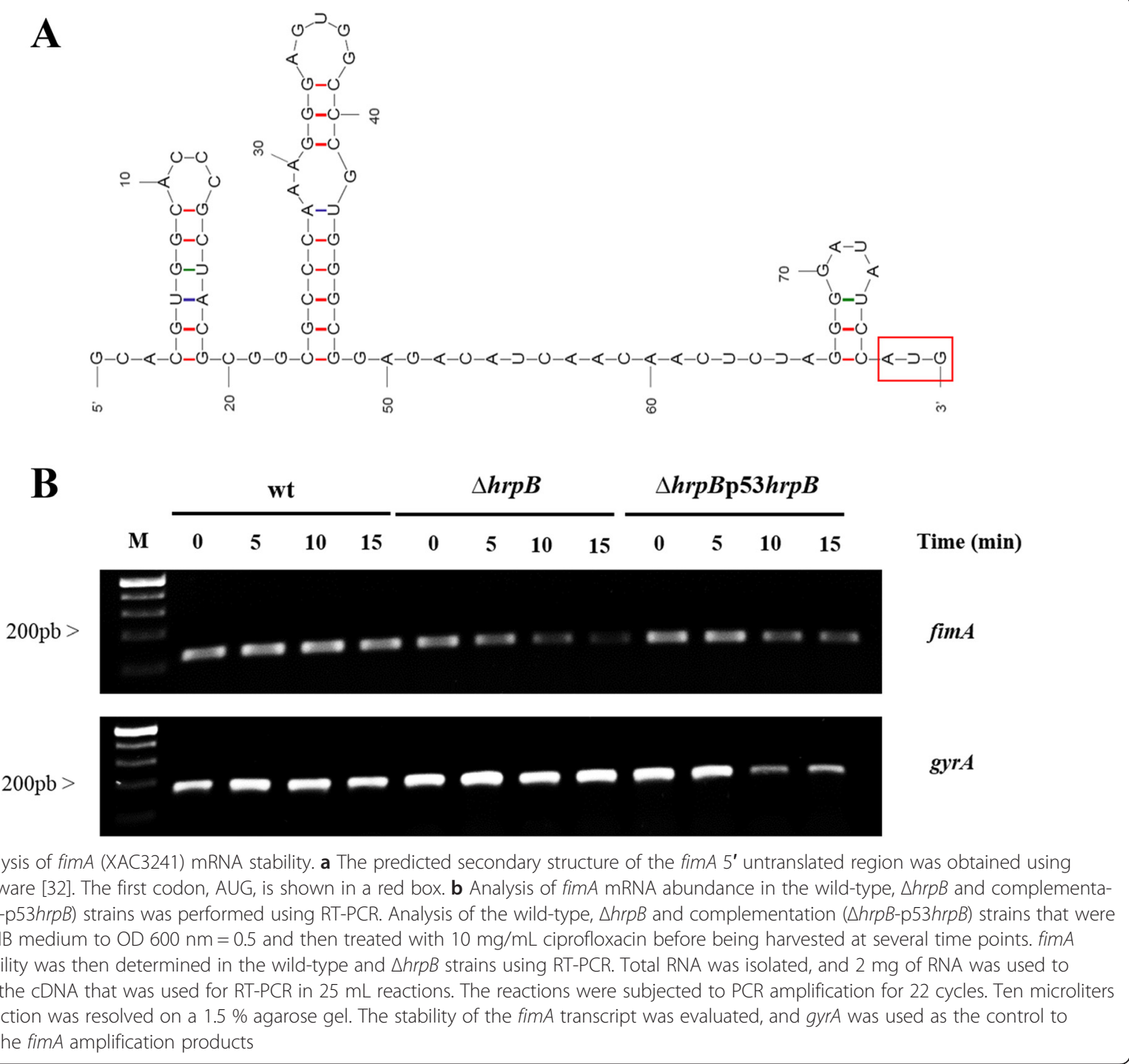

mRNA secondary structures in the 5' UTR can dramatically influence the initiation of translation [44]. Thus, the interaction between $\operatorname{HrpB}$ and $\operatorname{fim} A$ leader sequences may function by unwinding the secondary structure in the 5' UTR of the mRNA to enable binding and scanning by the small ribosomal subunit to the start codon, AUG, resulting in an increase in the translation efficiency of this mRNA in $X$. citri cells. It has been shown in Bacillus subtilis that two cold-induced putative DEAD-box RNA helicases, CshA and CshB, destabilize the secondary structures in mRNA that prevent the initiation of translation so that the single-stranded mRNA can be successively bound by cold shock proteins to prevent refolding until translation is initiated at the ribosome [10]. Similarly, in E. coli, a DEAH-box RNA helicase that is involved in the processing of the mRNA of a fimbrial operon is required to alter the RNA structure element that is upstream of the processing site, which consequently increases the stability and translation of the fimbrial transcript [13]. These results suggest that the degree to which translation is inhibited in the hrpB mutant was correlated with the 5' UTR secondary structure of the fimA mRNA.

Translational repression often leads to the rapid decay of mRNA [45]. When the translation of mRNA is inhibited, transcripts are generally more susceptible to degradation by RNase E [46]. Consistent with these findings, an assay used to assess $\operatorname{fim} A$ stability revealed that the mRNA of $\triangle h r p B$ was less stable than that of the wild- type (Fig. 8), which would account for the reduced steady-state levels of the mRNA. These data were then reinforced by our qRT-PCR data. These findings allowed us to speculate about different possibilities that might explain fimA mRNA decay observed in the mutant. Our first hypothesis was that $\mathrm{HrpB}$ may unwind the loops in the $5^{\prime}$ UTR of the fimA mRNA to enable ribosomal 
binding, which protects the mRNA against decay. Previous studies have indicated that ribosome binding to a ribosome-binding site (RBS) assists in protecting mRNAs from attack by ribonucleases $[44,46]$. This notion is supported by studies that have examined the influence of RBS mutations on RNA decay [47]. For example, experiments in both $E$. coli and B. subtilis have shown that a variety of mRNAs can be significantly destabilized by mutations in the Shine-Dalgarno element that interfere with ribosome binding by markedly reducing complementarity to $16 \mathrm{~S}$ rRNA [46, 48]. Conversely, mutations that improve ribosome binding can prolong mRNA longevity [49]. Furthermore, a second possibility that may explain the reduced abundance of transcripts in $\triangle h r p B$ would be that HrpB is associated with the recruitment of other regulatory factors. In studies of other $\mathrm{DExD} / \mathrm{H}$ RNA helicases, it has been proposed that when one of these factors binds to a 5'UTR, it may modulate its activity physically to recruit a complex of proteins, which could potentially defend the 5'mRNA against decay $[1,13]$. However, to fully understand the role of HrpB in fimA mRNA stability, the factors that interact with this putative ATP-dependent RNA helicase need be identified and characterized. The third hypothesis involves the affinity of some ribonucleases to doublestranded RNA. Double-stranded RNAs are targeted by specific ribonucleases, such as RNAse III [49]. If HrpB destabilizes the loops in the 5'UTR of the fimA mRNA, the putative ribonuclease would not be able to bind to its target, and HrpB could thereby prevent the degradation of the mRNA.

The ATP-dependent RNA helicase HrpB appears to positively regulate the fimA mRNA in addition to other genes in the same operon that are involved in adherence, biofilm formation, motility and the development of citrus canker disease. Further biochemical studies are required to determine the mechanisms involving the HrpB protein in this process. To the best of our knowledge, this is the first time that a DEAH-box RNA helicase has been implicated in the regulation of type IV pili genes in Xanthomonas and the first time that a RNA helicase has been shown to be important for motility, biofilm formation and epiphytical survival.

\section{Conclusions}

In this work, we characterized the $h r p B$ gene, which encodes an ATP-dependent RNA helicase, in X. citri. We demonstrate that the HrpB protein in X. citri is involved in biofilm formation, motility and survival on leaf tissues. Quantitative reverse transcription-PCR assays indicated that deletion of $h r p B$ reduced the expression of three IV pili genes, including fimA. The fimA mRNA predicted structure indicated that the fimA 5' UTR may contain three different loops. The ATP-dependent RNA helicase $\mathrm{HrpB}$ appears to positively regulate the abundance of the mRNA of fimA by promoting the stability of the fimA RNA.

\section{Methods}

\section{Bacterial strains and growth conditions}

The bacterial strains and plasmids used in this study are listed in Table 2. E. coli DH5 $\alpha$ cells were grown at $37{ }^{\circ} \mathrm{C}$ in Luria-Bertani (LB) medium (1 (w/v) tryptone, $0.5(\mathrm{w} / \mathrm{v})$ yeast extract, and $1 \%(\mathrm{w} / \mathrm{v})$ sodium chloride, $\mathrm{pH} 7.5)$ shaking at $200 \mathrm{rpm}$ or on plates. X. citri wild-type (ampicillin-resistant) [25] and mutant strains were grown at $28^{\circ}$ $\mathrm{C}$ in nutrient broth (NB; Difco, Detroit, MI) shaking at $200 \mathrm{rpm}$ or on nutrient agar (NA; Difco, Detroit, MI) plates. When required, antibiotics were added at the

Table 2 Strains and plasmids used in this study

\begin{tabular}{|c|c|c|}
\hline Strains and plasmids & Characteristics & Reference or source \\
\hline \multicolumn{3}{|l|}{ Strains } \\
\hline Escherichia coli & & [50] \\
\hline $\mathrm{DH} 5 \mathrm{a}$ & F- recA1 endA1 hsdR17 supE44 thi-1 gyrA96 real1 $\triangle$ (argE-lacZYA) $169 \varnothing$ lazA $\triangle$ M15 & Promega \\
\hline \multicolumn{3}{|c|}{ Xanthomonas citri subsp. citri } \\
\hline 306 & Syn. X. axonopodis pv. citri strain 306; wild-type, Rf', Apr & {$[25,51]$} \\
\hline$\Delta h r p B(h r p B-)$ & hrpB (XAC0293): pNPTS138 derivative & This study \\
\hline$\triangle h r p B-p 53 h r p B(h r p B+)$ & hrpB (XAC0293) contained in pUFR053, $\mathrm{Gm}^{\mathrm{r}}$ & This study \\
\hline \multicolumn{3}{|l|}{ Plasmids } \\
\hline pGEM T-Easy & PCR cloning and sequencing vector, lac $Z, A^{r}$ & Promega \\
\hline pNPTS138 & $\mathrm{Km}^{\mathrm{r}}, \mathrm{sacB}, \mathrm{lacZ \textrm {a } ^ { + }}$ & M. R. Alley, unpublished \\
\hline pUFR053 & IncW Mob mob (P) lacZa ${ }^{+}$Part, $\mathrm{Cm}^{r}, \mathrm{Gm}^{r}, \mathrm{Km}^{r}$, shuttle vector & [52] \\
\hline pNPTS_hrpB & hrpB (XAC0293) gene cloning on pNPTS138 & This study \\
\hline p53_hrpB & hrpB (XAC0293) gene cloning on pUFR053 & This study \\
\hline
\end{tabular}

$\mathrm{Ap}^{\mathrm{r}}, \mathrm{Cm}^{\mathrm{r}}, \mathrm{Gm}^{\mathrm{r}}, \mathrm{Km}^{\mathrm{r}}$, and $\mathrm{Rf}^{\mathrm{r}}$ indicate resistance to ampicillin, chloromycetin, gentamicin, kanamycin and rifamycin, respectively 
following concentrations: ampicillin (Ap) $100 \mu \mathrm{g} / \mathrm{mL}$ and gentamycin $(\mathrm{Gm}) 5 \mu \mathrm{g} / \mathrm{mL}$.

\section{DNA manipulations}

Bacterial genomic DNA and plasmid DNA were extracted using a Wizard genomic DNA purification kit and a Wizard miniprep DNA purification system according to the manufacturer's instructions (Promega, Madison, WI, USA). The concentration and purity of the DNA were determined using a Nanodrop ND-1000 spectrophotometer (NanoDrop Technologies, Wilmington, DE, USA). PCR was performed using standard procedures [53] with Pfu DNA polymerase (Promega Corporation, Madison, WI). The restriction digestions and DNA ligations were performed according to the manufacturer's instructions (New England Biolabs, USA).

\section{Construction of the $h r p B$ deletion mutant and the complemented strain of $X$. citri}

To construct the $h r p B$ deletion mutant, approximately $1 \mathrm{~kb}$ of the upstream and downstream regions of the $h r p B$ gene (XAC0293) was amplified using PCR from genomic DNA obtained from $X$. citri strain 306 using the following primer pairs: 0293mF1Hind (5' CGTGTTCACCGAGGACAGTG GCCTG 3') and 0293mR1Bam (5' ATAAGGATCCAA AAGCGGGGTCGGTCATGC 3'); and 0293F2Bam (5' CT ATGGATCCGGCACCTGAAACACATGGACC $3^{\prime}$ ) and 0293mR2Hind (5' GAATAAGCTTTGCTGCCGGTGGTG GATTGTG 3'), respectively. The PCR products were digested with BamH1, and both fragments were ligated to produce a deletion construct. The resulting fragment was cloned into the pNPTS138 suicide vector (M. R. Alley, unpublished) to generate pNPTS_hrpB (Table 2) using the restriction enzymes EcoR1 and HindIII. The plasmids were introduced into $E$. coli by heat-shock at $42{ }^{\circ} \mathrm{C}$ according to standard procedures [53] and into $X$. citri by electroporation [54]. The wild-type copy was replaced with the deleted version after two recombination events as previously described [55]. All of the obtained clones were confirmed using PCR.

To complement the $h r p B$ knockout mutant, a 2800bp DNA fragment containing the entire $h r p B$ gene plus approximately $300 \mathrm{bp}$ of neighboring region was amplified by PCR using total DNA obtained from the $X$. citri wildtype strain 306 as the template and the specific primer pair 0293_p53_F (5'AGGAAAAACATATGGGTACCTT TCCGATCTCCCCGTTATTGCC 3') and 0293_p53_R (5'AGGAAGGATCCTGCGGTACCGGTGCCACGTGG TTTTGCTCTGT 3'). The amplified DNA fragment was cloned into pUFR053 [52] at the KpnI restriction site to obtain the recombinant plasmid p53_hrpB (Table 2), which was used for genetic complementation. The construction was confirmed using sequencing. The recombinant plasmid p53_hrpB was transferred into $\Delta h r p B$ using electroporation, and cells were selected on NA using gentamicin, resulting in the strain $\triangle h r p B$-p53hrpB (hrpB+) (Table 2).

\section{Biofilm formation assays}

Biofilms that formed on polystyrene and glass surfaces were examined as previously described [56], with modifications. After 24, 48 and $72 \mathrm{~h}$ of incubation, optical density was measured at $590 \mathrm{~nm}$, and the data were normalized at an OD of $600 \mathrm{~nm}$. Quantitative measurements of 24 replicates were performed for each X. citri evaluated strain. Assays of biofilm formation on leaf surfaces were performed as previously described [22]. Briefly, a $20 \mu \mathrm{L}$ volume of each bacterial suspension $\left(10^{8} \mathrm{CFU} / \mathrm{mL}\right)$ was incubated on the abaxial surface of Valencia sweet orange leaves, which were maintained at $28{ }^{\circ} \mathrm{C}$ in a humidified chamber. At 24,48 and $72 \mathrm{~h}$ after the start of incubation, biofilm formation was visualized on the leaf surfaces using crystal violet staining. Leaf discs from staining spots were excised, dissolved in $1 \mathrm{~mL}$ ethanol:acetone (70:30, v/v) and quantified by measuring the optical density at $590 \mathrm{~nm}$. Data from both experiments were statistically analyzed using one-way analysis of variance (ANOVA) $(p<0.05)$, and values are expressed as the means \pm standard deviations.

\section{Motility assays}

To test cell motility, bacteria were grown overnight in NB medium. A $3 \mu \mathrm{L}$ volume of bacterial cultures with OD $600=0.3$ was then spotted onto the surface of a plate containing SB medium plus $0.5 \%$ ( $\mathrm{wt} / \mathrm{vol}$ ) agar (Difco, Franklin Lakes, NJ) [27] for the sliding motility tests or NYGB medium $0.25 \%$ (wt/vol) agar [19] for the swimming motility tests. Plates were incubated at $28{ }^{\circ} \mathrm{C}$ for $48 \mathrm{~h}$. The diameters of the circular halos that were occupied by the strains were measured, and the resulting values were taken to indicate the motility of $X$. citri strains. The experiments were repeated three times with three replicates each time. The diameter measurements were statistically analyzed using one-way analysis of variance (ANOVA) $(p<0.05)$, and the values are expressed as the means \pm standard deviations of three independent experiments.

\section{Pathogenicity assays}

Pathogenicity assays were performed as previously described [39]. Briefly, fully expanded, immature leaves were obtained from young (approximately 10-weekold) sweet orange (Citrus sinensis cv. Valencia) plants that were prepared in a quarantined greenhouse at the Citrus Research and Education Center (Lake Alfred, FL). X. citri strains ( $X$. citri 306 wild-type, $\triangle h r p B$ and $\Delta h r p B-p 53 h r p B)$ that were grown in selective antibiotic NB medium overnight at $28{ }^{\circ} \mathrm{C}$ were 
centrifuged at $4800 \mathrm{rpm}$ and then resuspended in $1 \%$ phosphate buffer ( $\mathrm{pH}$ 7.0). Bacterial suspensions from each strain were inoculated by pressure infiltration $\left(10^{5} \mathrm{CFU} / \mathrm{ml}\right)$ and spraying $\left(10^{8} \mathrm{CFU} / \mathrm{mL}\right)$. Phosphate buffer was used as the control in non-infected plants. All plant inoculations involved a minimum of three immature leaves from each plant, and three plants were inoculated for each bacterial strain. The plants were kept in a greenhouse at the Citrus Research and Educational Center (Lake Alfred, FL, USA) at a temperature of $28 \pm$ $4{ }^{\circ} \mathrm{C}$ in high humidity for 21 days. Disease symptoms were photographed at 7, 14 and 21 days post-inoculation, and both tests were independently repeated two times.

\section{Epiphytic growth on citrus leaves}

To obtain measurements to analyze bacterial epiphytic survival, populations of the pathogen were isolated from the leaves that were inoculated by spraying as described above. At $0,7,14$ and 21 days post-inoculation, three leaves with similar sizes were randomly collected from three different plants. The leaves were immersed in $10 \mathrm{~mL}$ of $1 \%$ phosphate buffer in Falcon flasks $(50 \mathrm{~mL})$. Bacterial cells were collected and then vortexed for three minutes to homogenize the tissue. Epiphytic bacterial numbers were determined in serial dilutions of these suspension and then plated on NA medium with the appropriate antibiotics. Colonies were counted after 2 days of incubation at $28{ }^{\circ} \mathrm{C}$. The assays were independently repeated two times with three replicates.

\section{RNA extraction and quantitative reverse-transcription polymerase chain reaction (qRT-PCR)}

To quantitatively analyze gene expression, we used RNA obtained from $X$. citri wild-type and $h r p B$ mutant $(\triangle h r p B)$ strains using two methods: NB medium and the leaves of sweet orange plants that were inoculated by spraying. For the experiments performed using NB medium, the strains were grown in $10 \mathrm{~mL}$ of $\mathrm{NB}$ at $28^{\circ}$ $\mathrm{C}$ while shaking, and both bacterial cultures were collected in the middle exponential stage $(\mathrm{OD}=0.8)$. RNA was immediately stabilized by mixing it with 2 volumes of RNA-protecting bacterial reagent (Qiagen, CA, USA. It was then incubated at room temperature for $5 \mathrm{~min}$. Bacterial cells were centrifuged at 5,000 $\times \mathrm{g}$ for $10 \mathrm{~min}$, and the cell pellets were then treated with lysozyme. RNA extraction was then performed using an RNeasy minikit (Qiagen, Valencia, CA). For the epiphytical assays, 3 different plants were inoculated with each strain at $10^{8} \mathrm{CFU} / \mathrm{mL}$. At different timepoints after infection (1, 3 and 7 days after inoculation), three leaves were collected from each plant to perform RNA extraction using a RNase plant mini kit (Qiagen, CA, USA). Contaminated genomic DNA was removed from the RNA during both experiments by processing the preparation using a
TURBO DNA-free kit (Ambion, TX, USA), and RNA purity and quantity was determined using a ND-8000 Nanodrop spectrophotometer (NanoDrop Technologies, U.S.A.). For qRT-PCR assays, 4 genes in the T4P system (XAC3241, XAC3240, XAC3239 and XAC2924) were chosen for gene expression analyses using the primers shown in Table 3. Reverse transcription was performed using an iScript cDNA Synthesis kit (Bio-Rad) according to the manufacturer's protocol. Quantitative amplification of the resulting cDNA $(1 \mu \mathrm{g})$ was performed using $0.3 \mathrm{mM}$ of each primer (Table 3) and SYBR Green/ROX qPCR Master Mix (Qiagen) according to the kit instructions in an ABI7300 Real-Time System (Applied Biosystems). Relative expression was evaluated using the $2^{-\Delta \Delta C T}$ method. gyrA was used as the endogenous control. Both types of quantitative real-time PCR experiments were performed using three biological replicates.

\section{$5^{\prime}$ - RACE}

The transcriptional start site of fimA (XAC3241) was determined using a $3^{\prime} / 5^{\prime}$ RACE Kit (Roche) according to the manufacturer's instructions. Briefly, total RNA was obtained from $X$. citri wild-type cell cultures that were grown in NB medium to an OD 600 of 1.0. After treating the RNA using a TURBO DNA-free kit (Ambion, TX, USA), the RNA was reverse-transcribed using a genespecific primer (SP1, Table 4) and then purified before a poly $(\mathrm{dA})$ tail was added to its $3^{\prime}$ end in a reaction with a terminal transferase enzyme. The resulting cDNA was amplified using PCR with the poly-dT primer that was provided in the kit, which anneals at the poly $(\mathrm{dA})$ tail, and a gene-specific primer (SP2, Table 4) that was complementary to a region upstream of the original cDNA primer. The amplicons obtained from the first PCR were submitted to a second-round PCR reaction using the poly $\mathrm{dT}$ primer and a distinct gene-specific nested primer (SP3, Table 4) that was internal to the first primer. The PCR products were ligated into the pGEM-T vector (Promega), and three distinct clones were sequenced.

Table 3 Primers used for qRT-PCR

\begin{tabular}{ll}
\hline Genes & Sequences \\
\hline gyrA (XAC1631) & F, GCCTACATTTGACGGCCAC \\
fimA (XAC3241) & F, GACGACGAAGTGCTGTTGAT \\
fimA2 (XAC3240) & R, TATGTTGCCAAGTCGCAGGT \\
pilB (XAC3239) & R, TAGCAGTCGCAGTCAAACCA \\
pilT (XAC2924) & F, ATTGCTGGCCGAAGGATTCA \\
& R, TAATGCCGATGACCGACGAG \\
& F, GAATTCCTCGTAATCGCGCC \\
& R, CAGGTCCGATGCCTGTTCT \\
\hline
\end{tabular}


Table 4 Primers used for 5'- RACE

\begin{tabular}{ll}
\hline Primers & Sequences \\
\hline SP1 & CATAGTTCTGATACTGGGGCAGC \\
SP2 & GGCCAGACCAGCAGTGACCTG \\
SP3 & TCGTATTGCGTTTACCCGG \\
\hline
\end{tabular}

\section{mRNA stability assay}

Bacterial cultures of $X$. citri subsp. citri wild-type, $\Delta h r p B$ and the complementation strain $(\Delta h r p B-p 53 h r p B)$ were grown at $28{ }^{\circ} \mathrm{C}$ in $\mathrm{NB}$ medium to an OD $600 \mathrm{~nm}$ of 0.5 and then treated with ciprofloxacin at a final concentration of $10 \mathrm{mg} / \mathrm{ml}$ to inhibit transcription. Samples were collected at 0, 5, 10 and 15 min after treatment with ciprofloxacin. The cells were harvested by centrifugation at 5,000 rpm and used immediately to extract RNA using a RNeasy Mini kit (Qiagen, CA, U.S.A.). Total RNA samples were treated with Turbo RNase-free DNase (Ambion) and quantified using a Nanodrop. A total of $2 \mu \mathrm{g}$ of treated RNA was used for reverse transcription using an iScript cDNA Synthesis kit (Bio-Rad) according to the manufacturer's protocol. Reactions were subjected to PCR amplification for 22 cycles using $0.3 \mathrm{mM}$ of each of two primers, fimAF (5' GAAGCAACAGGGTTTCACGC 3') and fimAR (5'TATGTTGCCAAGTCGCAGG 3'), and Taq 2x Master Mix (Biolabs). Ten microliters of each reaction was resolved in a $1.5 \%$ agarose gel. Analyses of $g y r A$ were performed and used as the controls for normalizing the fimA amplified products.

\section{Additional file}

Additional file 1: Figure S1. Pathogenicity assay of $X$. citri subsp. citri strains in planta. Symptoms were analyzed on the lower the surfaces of sweet orange leaves at 21 days post-inoculation (d.p.i.) of wild-type, $\triangle h r p B$ and a complementary strain of $X$. citri that were inoculated on the sweet orange leaves by infiltration the leaves with bacteria at a concentration of $10^{5}$ CFU/ $\mathrm{mL}$. Abbreviations: wt-p53, wild-type strain 306 with empty vector pUFR053; $\triangle h r p B$, hrpB mutant; and $\triangle$ hrpB-p53hrpB, complemented hrpB mutant. (PNG $1241 \mathrm{~kb}$ )

\section{Competing interests}

The authors declare that they have no competing interests.

\section{Authors' contributions}

AAS, MAT, SCP and MAM conceived the project. LMG, MAO and SCP designed and performed the experiments. LMG, MAO, AAS, MAT and NW analyzed the data and wrote the paper. All authors read and approved the final manuscript.

\section{Acknowledgements}

This work has been supported by INCT Citrus and a CAPES/PSDE fellowship (99999.002657/2014-07). LMG is a CAPES PhD fellow. MAM and AAS are recipients of research fellowships from CNPq

\section{Author details}

'Centro de Citricultura Sylvio Moreira/IAC, Rodovia Anhanguera Km 158, Cordeirópolis, SP 13490-970, Brazil. ²Universidade Estadual de Campinas/ UNICAMP, Instituto de Biologia, P.O. Box 6010, Campinas, SP 13083-970, Brazil. ${ }^{3}$ Citrus Research and Educational Center, Department of Microbiology and Cell Science, University of Florida, IFAS, 700 Experiment Station Road, Lake Alfred, FL 33850, USA.

Received: 30 June 2015 Accepted: 2 March 2016

Published online: 23 March 2016

References

1. Silverman E, Edwalds-Gilbert G, Lin RJ. DExD/H-box proteins and their partners: helping RNA helicases unwind. Gene. 2003:312:1-16.

2. Cordin O, Banroques J, Tanner NK, Linder P. The DEAD-box protein family of RNA helicases. Gene. 2006:367:17-37.

3. Tanner NK, Linder P. DExD/H box RNA helicases: from generic motors to specific dissociation functions. Mol Cell. 2001:8:251-62.

4. Caruthers JM, McKay DB. Helicase structure and mechanism. Curr Opin Struct Biol. 2002;12:123-33.

5. Rocak S, Linder P. DEAD-box proteins: the driving forces behind RNA metabolism. Nat Rev Mol Cell Biol. 2004;5(March):232-41.

6. Oun S, Redder P, Didier J, François P, Corvaglia A, Buttazzoni E, Giraud C, Girard M, Schrenzel J, Linder P. The CshA DEAD-box RNA helicase is important for quorum sensing control in Staphylococcus aureus. RNA Biol. 2013;10(1):157-65.

7. Gong Z, Dong C-H, Lee H, Zhu J, Xiong L, Gong D, Stevenson B, Zhu J-K. A DEAD box RNA helicase is essential for mRNA export and important for development and stress responses in Arabidopsis. Plant Cell. 2005; 17(January):256-67.

8. Kaberdin VR, Bläsi U. Bacterial helicases in post-transcriptional control. Biochim Biophys Acta - Gene Regul Mech. 1829:2013:878-83.

9. Linder P, Jankowsky E. From unwinding to clamping - the DEAD box RNA helicase family. Nat Rev Mol Cell Biol. 2011;12:505-16.

10. Hunger K, Beckering CL, Wiegeshoff F, Graumann PL, Marahiel MA. Coldinduced putative DEAD box RNA helicases CshA and CshB are essential for cold adaptation and interact with cold shock protein B in Bacillus subtilis. J Bacteriol. 2006;188:240-8.

11. Roos $\mathrm{S}$, Lindgren $\mathrm{S}$, Jonsson $\mathrm{H}$. Autoaggregation of Lactobacillus reuteri is mediated by a putative DEAD-box helicase. Mol Microbiol. 1999;32:427-36.

12. Markkula A, Mattila M, Lindström M, Korkeala H. Genes encoding putative DEAD-box RNA helicases in Listeria monocytogenes EGD-e are needed for growth and motility at $3{ }^{\circ} \mathrm{C}$. Environ Microbiol. 2012;14:2223-32.

13. Koo JT, Choe J, Moseley SL. HrpA, a DEAH-box RNA helicase, is involved in mRNA processing of a fimbrial operon in Escherichia coli. Mol Microbiol. 2004;52:1813-26.

14. Butland G, Peregrin-Alvarez JM, Li J, Yang W, Yang X, et al. Interaction network containing conserved and essential protein complexes in Escherichia coli. Nature. 2005;433(February):531-37.

15. Salman-Dilgimen A, Hardy PO, Dresser AR, Chaconas G. HrpA, a DEAH-Box RNA helicase, is involved in global gene regulation in the Lyme disease spirochete. PLoS One. 2011:6:e22168.

16. Gottwald TR, Pierce F, Graham JH. Citrus canker: the pathogen and its impact plant health progress plant health progress. Plant Heal Prog. 2002;1993:August.

17. Graham JH, Gottwal TR, Cubero J, Achor DS. Xanthomonas axonopodis pv. citri : factors affecting successful eradication of citrus canker. Mol Plant Pathol. 2004;5:1-15.

18. Rigano LA, Siciliano F, Enrique R, Sendín L, Filippone P, Torres PS, Qüesta J, Dow JM, Castagnaro AP, Vojnov AA, Marano MR. Biofilm formation, epiphytic fitness, and canker development in Xanthomonas axonopodis pv. citri. Mol Plant Microbe Interact. 2007;20:1222-30.

19. Malamud F, Torres PS, Roeschlin R, Rigano LA, Enrique R, Bonomi HR, Castagnaro AP, Marano MR, Vojnov AA. The Xanthomonas axonopodis pv. citri flagellum is required for mature biofilm and canker development. Microbiology. 2011;157(Pt 3):819-29.

20. Malamud F, Homem RA, Conforte VP, Yaryura PM, Castagnaro AP, Marano $M R$, et al. Identification and characterization of biofilm formation-defective mutants of Xanthomonas citri subsp. citri. Microbiology. 2013.

21. Li J, Wang N. Genome-wide mutagenesis of Xanthomonas axonopodis pv. citri reveals novel genetic determinants and regulation mechanisms of biofilm formation. PLoS One. 2011;6:e21804.

22. Li J, Wang N. Foliar application of biofilm formation-inhibiting compounds enhances control of citrus canker caused by Xanthomonas citri subsp. citri. Phytopathology. 2014;104:134-42.

23. Costerton JW, Lewandowski Z, Caldwell DE, Korber DR, Lappin-Scott HM. Microbial biofilms. Annu Rev Microbiol. 1995;49:711-45.

24. Caserta R, Takita MA, Targon ML, Rosselli-Murai LK, De Souza AP, Peroni L, Stach-Machado DR, Andrade A, Labate CA, Kitajima EW, Machado MA, De 
Souza AA. Expression of Xylella fastidiosa fimbrial and afimbrial proteins durine biofilm formation. Appl Environ Microbiol. 2010;76:4250-9.

25. da Silva ACR, Ferro JA, Reinach FC, Farah CS, Furlan LR, Quaggio RB, MonteiroVitorello CB, Van Sluys MA, Almeida NF, Alves LMC, do Amaral AM, Bertolini MC, Camargo LEA, Camarotte G, Cannavan F, Cardozo J, Chambergo F, Ciapina LP, Cicarelli RMB, Coutinho LL, Cursino-Santos JR, El-Dorry H, Faria JB, Ferreira AJS, Ferreira RCC, Ferro MIT, Formighieri EF, Franco MC, Greggio CC, Gruber A, et al. Comparison of the genomes of two Xanthomonas pathogens with differing host specificities. Nature. 2002;417(May):459-63.

26. Dunger $\mathrm{G}$, Guzzo CR, Andrade MO, Jones JB, Farah CS. Xanthomonas citri subsp. citri type IV Pilus is required for twitching motility, biofilm development, and adherence. Mol Plant Microbe Interact. 2014;27:1132-47.

27. Guzzo CR, Salinas RK, Andrade MO, Farah CS. PILZ protein structure and interactions with PILB and the FIMX EAL domain: implications for control of type IV pilus biogenesis. J Mol Biol. 2009;393:848-66.

28. Guzzo CR, Dunger G, Salinas RK, Farah CS. Structure of the PilZ-FimXEAL-Cdi-GMP complex responsible for the regulation of bacterial type IV pilus biogenesis. J Mol Biol. 2013;425:2174-97.

29. Finn RDA, Bateman J, Clements P, Coggill RY, Eberhardt SR, Eddy A, Heger K, Hetherington L, Holm J, Mistry ELL, Sonnhammer J, Tate MRD, Finn A, Bateman J, Clements P, Coggill RY, Eberhardt SR, Eddy A, Heger K, Hetherington M. The Pfam protein families database: 2014.

30. Xu Y, Xu X, Lan R, Xiong Y, Ye C, Ren Z, Liu L, Zhao A, Wu LF, Xu J. An O island 172 encoded RNA helicase regulates the motility of Escherichia coli 0157:H7. PLoS One. 2013;8:1-9.

31. Chiang P, Sampaleanu LM, Ayers M, Pahuta M, Howell PL, Burrows LL. Functional role of conserved residues in the characteristics secretion NTPase motifs of the Pseudomonas aeruginosa type IV pilus motor proteins PilB, PilT and PilU. Microbiology. 2008;154:114-26.

32. Zuker M. Mfold web server for nucleic acid folding and hybridization prediction. Nucleic Acids Res. 2003;31:3406-15.

33. Gottig N, Garavaglia BS, Garofalo CG, Orellano EG, Ottado J. A filamentous hemagglutinin-like protein of Xanthomonas axonopodis pv. citri, the phytopathogen responsible for citrus canker, is involved in bacterial virulence. PLoS One. 2009:4:e4358.

34. Py B, Higgins CF, Krisch HM, Carpousis AJ, Carpousis AJ. A DEAD-box RNA helicase in the Escherichia coli RNA degradosome. Lett to Nat. 1996;381:169-72.

35. Khemici V, Toesca I, Poljak L, Vanzo NF, Carpousis AJ. The RNase E of Escherichia coli has at least two binding sites for DEAD-box RNA helicases: functional replacement of RhIB by RhIE. Mol Microbiol. 2004;54:1422-30.

36. Danhorn T, Fuqua C. Biofilm formation by plant-associated bacteria. Annu Rev Microbiol. 2007;61:401-22.

37. Gottig N, Garavaglia BS, Garofalo CG, Zimaro T, Sgro GG, Ficarra FA, Dunger G. Mechanisms of infection used by Xanthomonas axonopodis pv. citri in citrus canker disease. 2010:196-204

38. Guo Y, Sagaram US, Kim J, Wang N. Requirement of the galU gene for polysaccharide production by and pathogenicity and growth In Planta of Xanthomonas citri subsp. citri. Appl Environ Microbiol. 2010;76:2234-42.

39. Yan Q, Wang N. The ColR/ColS two-component system plays multiple roles in the pathogenicity of the citrus canker pathogen Xanthomonas citri subsp. citri. J Bacteriol. 2011;193:1590-9.

40. Zimaro T, Thomas L, Marondedze C, Sgro GG, Garofalo CG, Ficarra FA, Gehring C, Ottado J, Gottig N. The type III protein secretion system contributes to Xanthomonas citri subsp. citri biofilm formation. BMC Microbiol. 2014;14:96.

41. Li J, Wang N. The gpsX gene encoding a glycosyltransferase is important for polysaccharide production and required for full virulence in Xanthomonas citri subsp. citri. BMC Microbiol. 2012;12:31.

42. Gury J, Barthelmebs L, Cavin JF. Random transposon mutagenesis of Lactobacillus plantarum by using the pGh9:ISS1 vector to clone genes involved in the regulation of phenolic acid metabolism. Arch Microbiol. 2004; 182:337-45.

43. Tu Quoc PH, Genevaux P, Pajunen M, Savilahti H, Georgopoulos C, Schrenzel J, Kelley WL. Isolation and characterization of biofilm formation-defective mutants of Staphylococcus aureus. Infect Immun. 2007;75:1079-88.

44. Andrade MO, Farah CS, Wang N. The post-transcriptional regulator rsmA/csrA activates T3SS by stabilizing the 5' UTR of hrpG, the master regulator of hrp/hrc genes, in Xanthomonas. PLoS Pathog. 2014;10:1-19.

45. Babitzke P, Romeo T. CsrB sRNA family: sequestration of RNA-binding regulatory proteins. Curr Opin Microbiol. 2007;10:156-63.

46. Richards J, Luciano DJ, Belasco JG. Influence of translation on RppH-dependent mRNA degradation in Escherichia coli. Mol Microbiol. 2013;86:1063-72.
47. Deana A, Belasco JG. Lost in translation: the influence of ribosomes on bacterial mRNA decay. Genes Dev. 2005;19:2526-33.

48. Arnold TE, Yu J, Belasco JG. mRNA stabilization by the ompA 5' untranslated region: two protective elements hinder distinct pathways for mRNA degradation. RNA. 1998:4:319-30.

49. Matsunaga J, Simons EL, Simons RW. Escherichia coli RNase III (rnc) autoregulation occurs independently of rnc gene translation. Mol Microbiol. 1997;26:1125-35.

50. Hanahan D. Studies on transformation of Escherichia coli with plasmids. Jol Biol. 1983;166:557-80.

51. Schaad NW, Postnikova E, Lacy GH, Sechler A, Agarkova I, Stromberg PE, Stromberg VK, Vidaver AK: Reclassification of Xanthomonas campestris pv. citri (ex Hasse 1915) Dye 1978 forms A, B/C/D, and E as X. smithii subsp. citri (ex Hasse) sp. nov. nom. rev. comb. nov., X. fuscans subsp. aurantifolii (ex Gabriel 1989) sp. nov. nom. rev. comb. nov., and X. Syst Appl Microbiol. 2005:28:494-518.

52. El Yacoubi B, Brunings AM, Yuan Q, Shankar S, Gabriel DW. In planta horizontal transfer of a major pathogenicity effector gene. Appl Environ Microbiol. 2007;73:1612-21.

53. Sambrook J, Fritsch E, Maniatis T. Molecular Cloning, vol. 1. 4th ed. New York: Cold Spring Harbor Laboratory Press; 2012.

54. Amaral AM, Toledo CP, Baptista JC, Machado MA. Transformation of Xanthomonas axonopodis pv. citri by Electroporation. 2005, 30:1995-1997.

55. Souza DP, Andrade MO, Alvarez-Martinez CE, Arantes GM, Farah CS, Salinas RK. A component of the Xanthomonadaceae type IV secretion system combines a VirB7 motif with a N0 domain found in outer membrane transport proteins. PLoS Pathog. 2011;7:e1002031.

56. Li J, Wang N. The wxacO gene of Xanthomonas citri ssp. citri encodes a protein with a role in lipopolysaccharide biosynthesis, biofilm formation, stress tolerance and virulence. Mol Plant Pathol. 2011;12:381-96.

\section{Submit your next manuscript to BioMed Central and we will help you at every step:}

- We accept pre-submission inquiries

- Our selector tool helps you to find the most relevant journal

- We provide round the clock customer support

- Convenient online submission

- Thorough peer review

- Inclusion in PubMed and all major indexing services

- Maximum visibility for your research

Submit your manuscript at www.biomedcentral.com/submit
C Biomed Central 